\title{
ADELAIDE AS AN ABORIGINAL LANDSCAPE
}

\author{
Philip A. Clarke
}

\section{Introduction}

The relationships pre-European Aboriginal people had with their landscape were complex. Nevertheless, the reconstructive ethnographic literature for southern South Australia has tended to regard Aboriginal geographic knowledge as having been the product of 'tribal' relations with a more or less constant area of terrestrial landscape. ${ }^{1}$ The erroneous belief in cultural homogeneity within the 'tribe', has led various researchers to look for 'true' expressions of a culture, such as portrayed by myth. Nevertheless, evidence provided by the early ethnographies indicates that there were wide ranging geographic views within cultural groups. Furthermore, the recorded mythology of many Aboriginal cultures illustrates perceived connections with distant landscapes. In this paper, I account for the diverse range of links to the landscape that Adelaide Aboriginal people possessed. This is a study in cultural geography, considering both material and nonmaterial aspects of Aboriginal cultural construction of the landscape.

\section{The historical background}

The primary focus of this paper is Aboriginal land relationships prior to and during the early phases of European occupation. Much of the early Adelaide ethnographic material was derived from the observations of Europeans involved in the colonial welfare of Aboriginal people. From 1840 to 1846 , German missionaries, Schürmann, Teichelmann, and Meyer, provided detailed accounts of the Aboriginal inhabitants of the newly settled districts about Port Lincoln, Adelaide and Encounter Bay. ${ }^{2}$ Their deep academic interest in Aboriginal culture included an investigation of the existence of an Aboriginal 'Supreme Being' to facilitate Christianising processes. Most other early studies are based on data collected by these missionaries, with other sources, such as Williams, Gell, Cawthorne, Wilhelmi, and Taplin relying heavily on their data. ${ }^{3}$ Further accounts used in this paper, for instance Wyatt, Stephens and Finlayson, were recorded much later as reminiscences. ${ }^{4}$ In this

Philip A. Clarke is the Registrar of the Anthropological Division of the South Australian Museum. His research interests include the ethnobotany and Aboriginal cultural geography of southern South Australia. He is presently doing postgraduate research in the Aboriginal cultural geography of the Lower Murray.

1 Tindale 1936, 1940,1974, 1987 has an extreme view of what a 'tribe' represents. His influence on the southern South Australian ethnographic literature is significant, for instance see Groome 1981, 1983, 1986 and Ross 1984. Peterson 1976 provides an outline of the 'tribe' debate.

2 The published works of the German missionaries of this early period include Teichelmann and Schürmann 1840, Teichelmann 1841, Meyer 1843, and Schürmann 1844, 1879. However, the religious importance of their work is most evident in the Schuirmann Diaries (see entry for 19 June 1839).

3 Williams 1839; Gell 1988 ; Cawthorne 1926; Wilhelmi 1860; Taplin 1979, 1879.

4 Wyatt 1879; Stephens 1889; Finlayson 1903. 
century, 'Adelaide' ethnographic material was collected by the South Australian Museum ethnologist, Tindale, from an Aboriginal informant known as Ivaritji, who had lived in the Adelaide region during the early years of colonisation. ${ }^{5}$ A small vocabulary was also obtained from this person by Black. 6

Early ethnographic sources describe the Aboriginal people living in the vicinity of Adelaide simply as 'the Adelaide people' or 'the Adelaide tribe', in spite of their use of Aboriginal language names to classify the Parnkalla and Nauo of Eyre Peninsula (see Figure 1). For the Adelaide area, this reluctance probably reflected the existence of a descent group complex with varying affinities, not easily placed under one term derived from Aboriginal sources. In spite of the apparent failure by early sources to define the Adelaide people under one term, scholars in the early 1900s adopted the term 'Kauma' to represent this group, although it is not present in the Teichelmann and Schürmann data ${ }^{7}$. Since then, the reconstructive ethnographic work by Tindale has been a major influence on the confirmation of 'Kaurna' to mean the pre-European Adelaide people. According to him, the 'tribal' territory of the 'Kauma' extended along the shores of Saint Vincent Gulf from the tip of Cape Jervis, northwards to about Port Wakefield and inland to Crystal Brook, and then down the scarp of the Mount Lofty Ranges. However, it is my contention, taken up in a later section of this paper, that Tindale's 'Kaurna' population does not closely match the Adelaide population described by earlier ethnographers.

Exactly what happened to the original Adelaide population after the 1840 s, when the chief ethnographic studies were completed, still remains to be determined. These people increasingly found themselves peripheral to the Adelaide landscape as it was being conceived, and then developed by European invaders. The present pattern of where Aboriginal people live reflects this, with Adelaide descendants found among Aboriginal communities chiefly based on former mission settlements at Point Pearce on Yorke Peninsula, and Point McLeay near the Murray Mouth. ${ }^{8} \mathrm{~A}$ few families of Adelaide descent still retain the knowledge of their genealogical links to the Adelaide region. However, this present day Adelaide identity is to a large degree built upon the broader southern Aboriginal culture developed in response to colonisation. Since the mid 1970s, the desire of the wider Australian community to identify the original inhabitants, particularly for areas suffering intense European settlement, has facilitated the adoption of terms, such as 'Kaurna', for the

5 Tindale 1974 uses data from Ivaritji. Other names for Ivaritji include Amelia Savage and Amelia Taylor. Gara 1990 provides a life history of this person.

6 Black 1920.

7 The term 'Kaurna' possibly has a Lower Murray origin. For instance, 'Kaurna' was the 'tribe' of Encounter Bay Bob (Wyatt 1879:180). 'Coma' was a recorded Lower Murray term meaning Aboriginal people (Cuique in South Australian Magazine, Sept. 1842, vol.1, no.12:467-72). Similarly, 'Kornarrinyeri', from which 'Narrinyeri' was derived, reportedly meant 'men, belonging to' (Taplin 1979:1; 1879:34). Howitt 1904 maps 'Kaurna' as the Adelaide people. In 1926, the Anthropology Society of South Australia concluded that the 'Adelaide tribe' were the 'Kauma' (Minutes published in The Advertiser, 26 August 1926). Tindale used this definition in his surveys of Aboriginal 'tribe' distribution (1940:179; 1974:213).

8 Brock and Kartinyeri 1989 give a history of the Aboriginal settlement at Poonindie, near Port Lincoln, which was the precursor to Point Pearce. Kartinyeri 1983, 1985, 1989a, $1989 \mathrm{~b}, 1990$ provides family histories of some of the main southern South Australian Aboriginal families. 


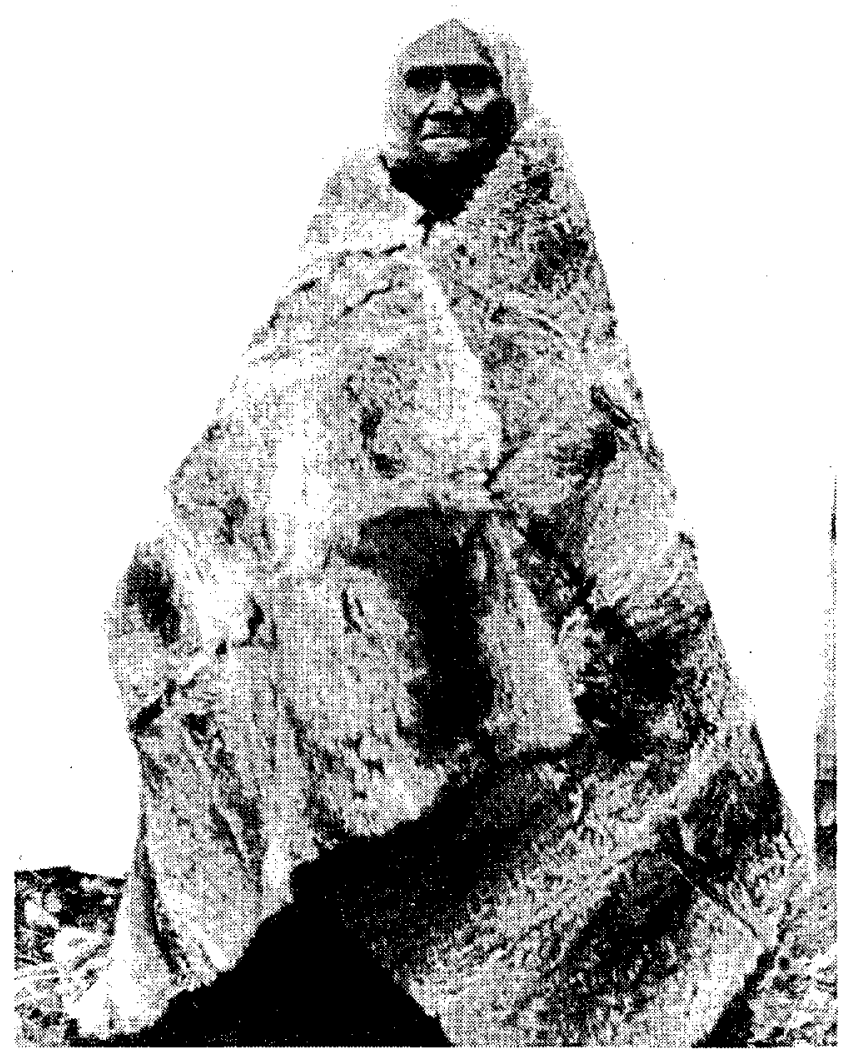

Ivaritji in a Museum possum skin cloak.

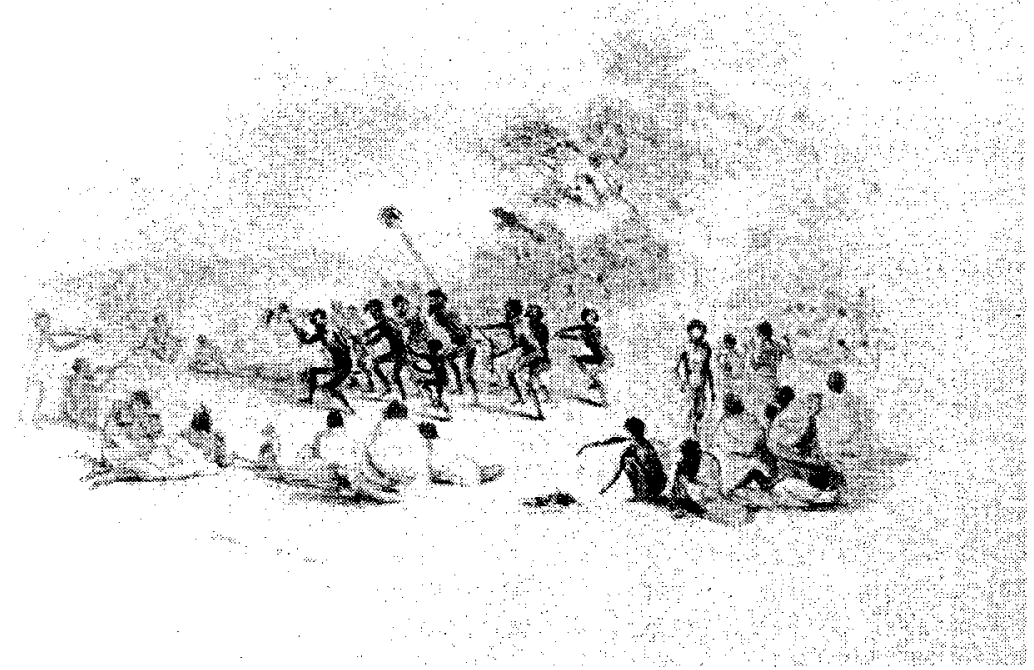

Painting by Angas of an Adelaide Kuri ('circle') dance. 

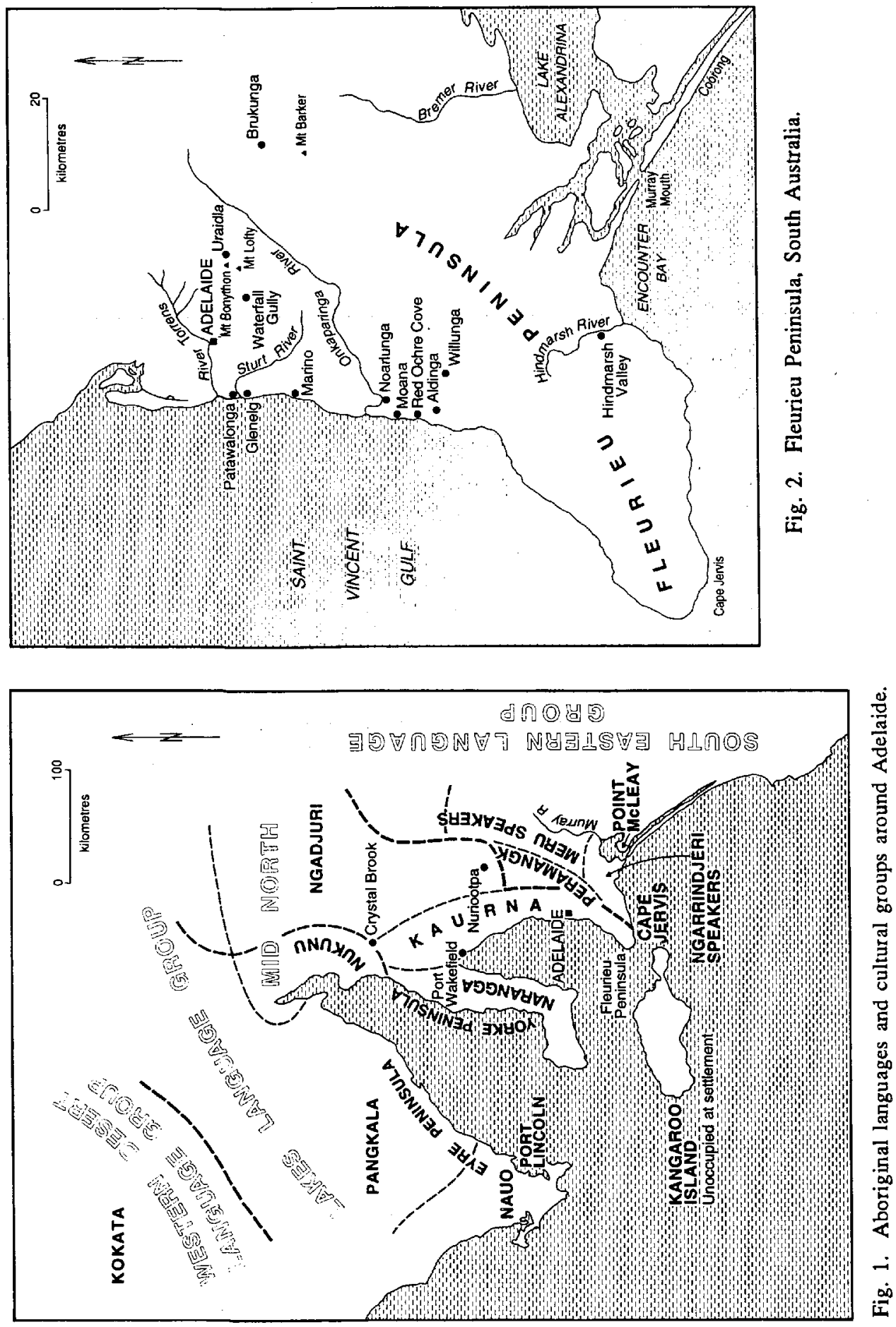
identity of pre-European Aboriginal groups inhabiting particular landscapes. ${ }^{9}$ Although modern definitions of what 'Kaurna' represents are important developments in contemporary Aboriginal expressions of their links to the past and to the Adelaide landscape, its treatment is beyond the scope of this paper. Amongst the early ethnographic accounts, there are a variety of spelling systems used, with particular Aboriginal words spelled several ways. In general, I have used the term that appears to have been provided by the most linguistically reliable source.

\section{Aborigines as active occupants of the landscape}

In pre-European times, the vegetation along the coast of the Fleurieu Peninsula ranged from coastal dune and swamp vegetation near Adelaide, through to predominately cliff and open woodland vegetation in the south, with mangrove and salt flats in the north. The inland regions were dominated by mallee vegetation interspersed with grassy plains. The relatively high rainfall areas about the Mount Lofty Ranges suited wet sclerophyll forests. People living in the vicinity of what was to become Adelaide, utilised several ecological zones for food sources, and the raw materials required in making tools, weapons, clothing and shelter. The Adelaide people had detailed ecological knowledge of their region, as shown by their use of different terms for various types of vegetation. Today, for instance, the mouth of the Sturt River entering Saint Vincent Gulf west of Adelaide, is still called the Patawalonga (see Figure 2). This was a place name used by Aboriginal people, reportedly meaning 'brushwood place'. ${ }^{10}$ Aboriginal place names in common use by Australians today, are essentially transformed Aboriginal cultural relics.

The subsistence strategy of Aboriginal groups in southern South Australia was a seasonal movement of people between the inland and coastal regions. ${ }^{11}$ Large numbers of Adelaide Aboriginal people gathered along the coast in the summer months, taking advantage of marine and sand dune-belt food resources, such as coastal berries, shellfish, crustacea, fish, turtles, nesting sea birds and occasional stranded whales. ${ }^{12}$ In autumn there was a general movement of people towards the foothills to make more substantial winter shelters there. ${ }^{13}$ This region would have had more firewood available, was close to inland forests where mammals were hunted, and yet was still near to aquatic food sources, such as bulrush roots and freshwater crayfish from the swamps and creeks of the Adelaide Plains. Although this coast/summer - inland/winter pattern was a quasi-sedentary life style, it would not have greatly restricted the utilisation of different ecological zones, due to the close proximity of the Mount Lofty Ranges to the sea. For example, foods such as red gum seed, leaf lerp, Acacia gum and plant nectar, were inland sources chiefly available in the warmer months when the bulk of the population was situated along the coast. The

9 Examples of the recent use of 'Kauma' include Ellis 1976, Ross 1984, Groome 1981, 1983, 1986, and Mattingley and Hampton 1988. The use of 'Kaurna' (or orthographic variations such as 'Gaurna') has been legitimised to the extent that it is listed as a major source language of European-Australian words in W.S.Ramson, The Australian National Dictionary, Oxford, 1988.

10 Black 1920:84.

11 Accounts of seasonal movements of Aboriginal people in southern South Australia are provided by Tindale 1974, Ellis 1968, 1976, Foster 1983 and Ross 1984.

12 Twidale et al 1976 provides information on the flora and fauna of the Adelaide region. Clarke 1985, 1986a, 1986b, 1987, 1988, 1989 outlines Aboriginal environment use in southern South Australia.

13 Tindale 1974:61; Gell 1988 


\section{ADELAIDE AS AN ABORIGINAL LANDSCAPE}

collecting of these foods would have occurred during regular trips from the coast to the inland regions. Changes of season were generally marked by the flowering of particular plants or the appearance of certain constellations in the heavens. For instance, the arrival of the star, Parna, signified autumn (parnatti). ${ }^{14}$ Similarly, spring (wiltutti) was said to be governed by a constellation called Wilto, recorded as meaning an eagle; the summer season (woltatti ) was governed by Wolta, the wild turkey constellation. 15 As with other Aboriginal groups in Australia, the Adelaide Aboriginal people positioned themselves in the landscape according to flexible seasonal patterns. 16

Aboriginal people have often been portrayed by scholars as being passive occupants of the pre-European environment. For example, Williams, in The making of the South Australian landscape, barely mentions the Aboriginal inhabitants. ${ }^{17}$ The environmental determinist approach has been a dominant paradigm in the studies of Aboriginal land relationships until relatively recent times. ${ }^{18}$ In contradiction to this view, a close inspection of ethnographic data from southern Australia suggests that Aboriginal inhabitants had a profound effect on the development of the biota of this region. ${ }^{19}$ For instance, early historical records from explorers and colonists describe the periodic burning of the Adelaide area by Aboriginal people, not only to drive out game, but as a resource management tool creating favoured vegetation types. ${ }^{20}$ The production of nutrient rich ashes and the destruction of the canopy stimulated new and succulent plant growth edible to humans, such as yam daisies, cresses and thistles, as well as increasing herbage species eaten by hunted animal species. This practice in other parts of Australia has been described by researchers as 'firestick farming'. ${ }^{21}$ In addition to the direct economic benefit of vegetation firing, there was value in opening up the landscape to allow for an easier passage. The wide open grasslands of the Fleurieu Peninsula, as painted by George French Angas in 1844,22 was the product of frequent firing by Aboriginal people. It is ironic that the open landscape that Aboriginal action created, was undoubtedly a major attraction of the Adelaide Plains for European colonisers.

Additional evidence for the pre-European existence of regular movement patterns is provided by an early statement that Aboriginal foraging groups in the Adelaide area, consisting of a man, his wives, children, and perhaps a few other kin-folk, generally moved their camps to places used the previous year. ${ }^{23}$ Furthermore, in some areas, the first settlers found well worn paths or tracks already in existence when they arrived. One major track ran from the Adelaide Plains southeast towards the Bremer River, continuing to the Murray. It

14 Teichelmann 1857; Gell 1988.

15 Teichelmann 1857.

16 Crawford 1982:17-19 and Davis 1989 give detailed accounts of seasonal cycles in northern Australia.

17 Williams 1974.

18 Elkin 1964 provides a typical environmentally deterministic account of the Aboriginal land use.

19 Descriptions of Aboriginal effects on southem Australian environments are given by Hallam 1975. Gott 1982, 1983, 1989 and Clarke 1986b, 1988.

20 Flinders 1814; Finlayson 1903:40-41; South Australian Gazette and Colonial Record, 9 March 1839.

21 Jones 1969.

22 Angas 1847.

23 Teichelmann 1841:7. 
was observed in frequent use by Aboriginal people in the early days of the colony. 24 Another track, made by Encounter Bay people, ran from Hindmarsh Valley to Willunga. ${ }^{25}$ Since this path was originally only two feet wide, its use by Europeans was initially confined to foot and horse traffic. Eventually, however, it was widened for coach use. In the pre-European period, the Aboriginal people would have travelled to other regions for economic purposes, such as trade, and for ceremonial occasions. Many of these well defined Aboriginal tracks were used by early settlers, the course of many of them almost certainly preserved today as bitumen roads. Across Australia, the absorption of Aboriginal pathways by Europeans is now widely recognised in the literature. ${ }^{26}$ Furthermore, the existence of tracks, and the seasonal shift of people, are strong indications that Aboriginal movements across the landscape had purpose. This evidence, together with the evidence for environmental management practices through burning, leads us to consider that Aboriginal people were active occupants of their landscape.

\section{Aboriginal social structure and the landscape}

In Aboriginal tradition, the Adelaide people originally came from country to the northeast. 27 Whether this assertion refers to the movement of people or cultural practices or both is difficult to ascertain. At the time of European settlement, the Adelaide people were the southern most Aboriginal group practising circumcision ceremonies on their young men, considering their neighbours not practising this rite to be paruru, a derisive term for 'uncircumcised' or 'animal'. ${ }^{28}$ The tattooing ceremonies were said to have been introduced by the spirit, Tarnda, a fact reflected in some of the pre-European place names, such as Tandanya for the city area of Adelaide. ${ }^{29}$ Tarnda later transformed himself into a red species of kangaroo. The nearest eastern neighbours to the Adelaide people were termed the Peramangk, who, although circumcising people like themselves, were feared as sorcerers. With cultural groups further east, such as from the Lower Murray Lakes and Murray River, the differences in religious beliefs with Adelaide were marked. It is therefore to be expected that Adelaide people were considered dangerous strangers to the southeastem Aboriginal groups. 30

To add to the differences in the religious sphere, the people to the east and southeast of the Adelaide Plains spoke very different languages. In the Murray River region, the speech has been termed Ngaiawung or Meru. 31 In the Lower Murray Lakes district, a region bounded by Encounter Bay, the Coorong and Wellington, the Ngarrindjeri group of dialects were spoken. ${ }^{32}$ Linguists believe that these two language groups had more affinity with Western Victorian languages than that of Adelaide; the latter more in common with languages to the north in the Lower Flinders Ranges and west to Eyre Peninsula and Yorke

\section{Stephens 1889:477.}

25 Sweetman 1928.

26 Reynolds 1990 provides a general summary of European use of Aboriginal pathways.

27 Stephens 1889:483 says that the Adelaide people believed they came from the northeast. Tindale 1974:73 supports this claim by stating that the Adelaide people had a tradition that they came from the north.

28 Tindale 1974:133,215.

29 Teichelmann and Schürmann 1840:2:75; Wyatt 1879:179.

30 Tindale 1974:60,61,73,217.

31 Taplin 1879:169; Moorhouse 1935:31.

32 Meyer 1843; Taplin 1979, 1879. 
Peninsula. ${ }^{33}$ Some suggest that the languages of the Narranga of Yorke Peninsula and the Ngadjuri of the Mid-North of South Australia, were simply dialects of the same language spoken by Adelaide people. ${ }^{34}$ This suggests a strong cultural relationship within the region bounded by Eyre Peninsula, the Mid-North, Mount Lofty Ranges, and the northern edge of Cape Jervis. Furthermore, similarities in mythology and ceremonial life within this area indicate that the views of the landscape of these groups would show some degree of affinity. Through strong links to related Aboriginal cultures, the Adelaide people would have had some knowledge of the landscape beyond the Fleurieu Peninsula region, particularly to the north. I therefore consider that my careful use of cultural information from groups within this larger region, to help interpret the Adelaide material, to be justified. In contrast, the Lower Murray/Victorian cultures to the southeast were formerly part of a very different cultural bloc than that of the Adelaide people. ${ }^{35} \mathrm{We}$ must therefore assume that the cultural connections between the Adelaide and Lower Murray people, with the possible exception of Encounter Bay groups, were restricted in pre-European times.

Aboriginal relationships to land existed on many levels. In the Adelaide area, each person had a strong kinship connection, traced mainly through the male line, to a particular piece of land, the pangkarra, defined as the territory of a locally based descent group. Teichelmann and Schïrmann ${ }^{36}$ state that 'As each pankarra [= pangkarra] has its peculiar name, many of the owners take that as their proper name, with the addition of the term burka; for instance ... Karkuyaburka, Tindoburka, etc'. Another example is Mullawirraburka, known by Europeans as King John, whose Aboriginal name literally translates as 'dry-forest-old man', referring to an area of mallee vegetation found inland from Aldinga. ${ }^{37}$ The pangkarra was a prominent marker of a particular descent group territory, and was associated with totemic species, such as possum or emu. However, an individual's pangkarra would not have restricted foraging movements. Each person would, with multiple kinship links to the pangkarra of others, some possibly through female lines, be able to range through a much larger district, this being the area of most economic exploitation.

An individual's interpretation of mythology, and its associated landscape, would have been affected by descent group affiliations. This aspect has been demonstrated for other Aboriginal groups, for instance among the Murngin, where 'clans', or descent groups, had their own local interpretation of particular ceremonies. ${ }^{38}$ In the Adelaide area, particular descent groups would have possessed detailed knowledge of mythical events having taken place in their own territory, but probably less information concerning events that took place further afield, and may not have had rights to speak of it. This cultural restriction in myth knowledge would lead to alternative explanations of some events, although probably the main outline of the whole myth would have varied less. It is therefore necessary to recognise that pangkarra descent groups would have provided their own modified view of the landscape.

Gender provides another selective view of the landscape. This is implicit in the descriptions by early ethnographers of the differing roles of Aboriginal men and women. The daily activities of an Adelaide Aboriginal person, as with many other Australian

33 Oates and Oates 1970.

34

35

36 Teichelmann and Schürmann 1840:2:36. Gell 1988 also describes the pangkarra.

37

38

Tindale 1936:55; Berndt 1940a:456.

Hemming and Clarke 1989.

Teichelmann and Schurmann 1840:2:4,75.

Wamer 1964:16. 


\section{ABORIGINAL HISTORY 1991 15:1}

groups, were to a large degree dictated by gender status. One account available of the division of labour in the Adelaide area is given by Teichelmann who says:

... the Aborigines, almost every day, in the bush, move their encampments, except [when] the male part are hunting, then the women and children stay for several days on the same place. When they leave for another encampment, which sometimes may be twenty miles distant, after they have breakfasted, and the men repaired their weapons, the women gathered the luggage and taken the children upon their backs; the men start first, carrying nothing but a small net bag and hunting implements, - the women burdened like camels, follow, gather and prepare on the road vegetable food for the night, whilst the men are looking out for meat; as it is the duty of the man to supply the family with animal food. The women and children generally arrive first at the place intended for an encampment ... here they fetch branches, fuel and water, and build a hut. When the men arrive, a fire is lighted, and the women deliver the vegetable food to the husband ... 39

It is clear from this account, that women and men had different economic roles, and would therefore have interacted differently with the environment. A woman's mental map of the landscape would have stressed places for gathering roots, collecting shellfish, giving birth and other such sites. In contrast, men would have considered places where plant food species of kangaroos and emus grew to be of greater concern. In other parts of Australia, Aboriginal women have had a different interpretation than men of much of the landscape mythology. 40 In the Adelaide region, Aboriginal women and men would probably have possessed conceptually different, although related, visions of the landscape.

\section{Land as body}

The Adelaide people, like other southern South Australian Aboriginal groups, perceived human-like qualities of their landscape, the reasons for which often stated in 'Dreaming' stories. ${ }^{41}$ In some accounts, the Adelaide people considered the surface of the earth to have been formerly without water courses. Such features were created by the spirit ancestor, Nganno, so that he could live upon freshwater crayfish and fish found in rivers. ${ }^{42}$ When Nganno's son, Gurltatakko, was killed, he travelled far and wide looking for the murderers. During Nganno's wanderings, he gave names to many of places about Adelaide. After finding and killing the slayers of Gurltatakko, his own kin fled into the sea. Nganno told them how not to respond, but they didn't heed him, saying such things as 'I am a shark', 'I am a whale'. These people were in this way transformed into sea creatures. Nganno eventually turned himself into a sea monster. The language used to tell this story was reportedly different from that normally spoken, being Munana Meyu - the language of the forefathers. The Narranga people of Yorke Peninsula had a myth, with similar elements, concerning a giant called Ngarna who created parts of their landscape. ${ }^{43}$ From available accounts, it is likely that Ngarna and Nganno are different regional interpretations of the same mythical being.

39 Teichelmann 1841:7.

40 Jacobs 1989.

41 For body elements of the Yorke Peninsula landscape, see Tindale 1936. Clarke 1991 outlines the body relationships to the Lower Murray landscape.

42 Schurmann, Personal diaries, 21 August 1839; Teichelmann and Schurmann 1840:5, 31; Teichelmann 1841:9. Variations in the recording of Nganno include Nadno and Nanno. 


\section{ADELAIDE AS AN ABORIGINAL LANDSCAPE}

The spine of the Mount Lofty Ranges was regarded by Adelaide people as the body of a giant ancestral man, who attacked the Adelaide people from the east and was killed there.44 The body of the fallen giant, whose name was not recorded, dominates the Fleurieu Peninsula from Nuriootpa in the north to Marino in the south, a distance of about 80 kilometres. Some Adelaide place names apparently refer to body parts of this being. For instance, the name of Adelaide Hills town, Uraidla, refers to the twin peaks of Mount Lofty and Mount Bonython being the ears of the giant, as yureilla reportedly means 'ear-two'.45 Mythology, often expressed in literature as the 'Dreaming', provided the framework for Aboriginal concepts of their relationship to their physical and social environments.

\section{The heavens}

No analysis of the cultural landscape would be complete without considering the way in which the heavens are spatially organised. Elsewhere I argue that the terrestrial spatial behaviour of the Adelaide people was influenced by perceived relationships between them and the sky world. ${ }^{46} \mathrm{I}$ have treated the sky world as a psychic landscape, defined as being that part of the total landscape without physical and tangible dimensions in a Western European sense. In Australia, there were widespread beliefs that 'clever men' could visit the sky world, and there acquire special knowledge such as healing. ${ }^{47}$ Novices were ritually taken to this celestial region as part of their initiation. In the Adelaide region, the relationships between cosmic bodies were mirrored in roles of initiation ceremony participants. ${ }^{48}$ The importance of the linkages between the sky world and the terrestrial world is further illustrated by Teichelmann who stated that Adelaide Aboriginal people: consider the firmament [heavens] with its bodies as a land similar to what they are living upon ... It is their opinion that all the celestial bodies were formerly living upon earth, partly as animals, partly as men, and that they left this lower region to exchange for the higher one. Therefore all the names which apply to the beings on earth they apply to the celestial bodies, and believe themselves to be obnoxious to their influence, and ascribe to them malformation of the body, and other accidents. 49

The amount of knowledge possessed of the heavens by the Adelaide people was said to be considerable. ${ }^{50}$ It is possible that the sky world was perceived as being entered from the east. Stephens ${ }^{51}$ says: 'At death they believed that the thinking and talking principle passed away to the east, whence came the sun and moon; that there they would all meet at last.'

There were several layers to the body of knowledge concerning the sky world. Teichelmann claims that Aboriginal beliefs about the world were limitedly known by Europeans, as they were carefully concealed, their own males only initiated with knowledge

44 Tindale 1974:64; Ross 1984:7.

45 Wyatt 1879:178-179; Webb 1937:308; Tindale 1974:64. Tindale refers to Yureilla as Jureidla. Word derivation from Teichelmann and Schürmann 1840:1:5.

46 Clarke 1990.

47 Elkin 1977; Berndt and Berndt 1981.

48 Gell 1988.

49 Teichelmann 1841:8. Teichelmann was quoted, without acknowledgment, by Cawthome 1926.

50 Teichelmann 1841:9.

51 Stephens 1889:482. 
of them at a certain age. ${ }^{52}$ Indeed, Schürmann's informants guarded their secrets so much that he was only told about the cosmos under the conditions that he would not tell another Aboriginal person. ${ }^{53}$ The stratification of knowledge among Adelaide people would have been reflected in varying landscapes' views held by differing age/gender groups. Rather than there being one valid cultural landscape per cultural group, there were many forms with a certain level of unity. The particular landscape view used in a given context would have depended on the cultural status of both the speaker and the listener. I argue that an analysis aiming towards an understanding of Aboriginal geography should not be limited to European landscape views emphasising physical or terrestrial characteristics. Cultural landscapes do not have an existence independent from the ideologies of their occupants.

\section{The land to the west and the underworld}

In addition to the sky world, ethnographic sources mention a psychic landscape variously described as the 'land to the far west', 'land of the dead', or 'the underworld'. It is here that the Adelaide people believed that a person's soul dwelt both before and after death. Unborn souls were considered to come from here to hover among grasstrees whilst awaiting the hour of conception. ${ }^{54}$ In describing these beliefs, the concept pinde needs explaining. The dual use of this term is shown by Teichelmann who states:

One opinion of theirs is, that the soul or the spirit is living in Pin-de, that is either in a western country, or in the grave; (for this term is applied both to the Europeans and to every hole digged [sic.] in the ground, therefore grave. 55

Pinde was therefore a landscape term applied to both the 'land to the west' and to 'the underworld'.

The earliest Aboriginal responses to contact with Europeans illustrate the significance of 'land to the west'. Teichelmann and Schürmann ${ }^{56}$ say that when the Adelaide people 'first saw the whites they took them to be the souls of their own forefathers, who ... had come back to see once more their native country'. Due to the configuration of Saint Vincent Gulf, Europeans were likely to have been first observed by Adelaide people as coming from predominately westerly directions. Kangaroo Island, to the southwest of Adelaide, was the base of European whalers and sealers as early as 1819, 17 years before the official formation of South Australia. ${ }^{57}$ These men periodically raided the mainland for Aboriginal women to act as wives and labourers. ${ }^{58}$ The experiences that southem South Australian Aboriginal people had with these Islanders in the precolonial period, would have shaped their perceptions of the official settlers arriving in 1836. By the Adelaide people assuming that the first Europeans came from the 'large den' in the west, they were simply making sense of the arrival of newcomers within the confines of their own cultural views of the landscape.

The relationship between 'pit' or 'den' with the western 'land' requires treatment. The Adelaide people considered the earth to be male, having under it three layers of water. 59

52 Teichelmann 1841:8.

53 The South Australian Colonist, 10 March 1840:23-24.

54 Gell 1988.

55 The South Australian Colonist, 7 July 1840:277.

56 Teichelmann and Schürmann 1840:2:5.

57 The Southern Australian, 28 September 1844: 5-6; The Adelaide Observer, 14 September 1895:16; Cumpston 1970 and Finnis (n.d.).

58 Clarke 1990.

59 Teichelmann 1841:9. 


\section{ADELAIDE AS AN ABORIGINAL LANDSCAPE}

Beneath this were two monsters considered to be the wives of the earth. Under these were three monsters continually uttering a deep roaring noise. Although the latter were not children of the former, they were nursed by them, presumably in the underworld. If the underworld was considered to be entered via the west, while, as suggested above, the sky world could be reached from the east, then it is logical that the underworid be equated with the 'land to the west'. It is likely that notions about the sun and the creation/death of the day are incorporated into the perceived existence of these psychic landscapes. It is to the west that the sun seemingly enters the earth, travelling through the underground landscape during the night to emerge in the east, the next day, to enter the celestial landscape.

\section{Where do souls go?}

To the early ethnographers, one of the confusing aspects of Adelaide Aboriginal religion was the large number of places the souls of the dead were perceived to go. Wyatt, for instance, recorded from Adelaide, that dead people go to islands or the land across the sea, dead dogs to Cadle Peendinga or the dog-country, and that kangaroos and other large animals go to Nanto country, nanto meaning all large animals. ${ }^{60}$ As stated above, some people and animals in spirit form travelled from the terrestrial landscape to the sky world. Another account is that, upon death, the spirit is firstly contained in the ground, this spot being the Wingkonnga, reportedly meaning 'breath-place'. 61 The carth here was made into a heap by the dead man's female relatives, while the body was carried away on a bier. This small mound was considered to draw up wingko or breath of the deceased to release it. Presumably another part of the soul accompanied the body until the inquest and mourning rituals were over. Birds appear to have an important perceived role in assisting souls in their journeys. In the Port Lincoln area of southern Eyre Peninsula, souls of dead people were believed to be accompanied to the 'land of the dead' by a kind of sea-bird with a red-bill, well known for its loud shrill call at night. ${ }^{62}$ In the Adelaide region, the call of a hawk, karkanya, had the power to charm away souls, particularly those of children. ${ }^{63}$ At least some birds, through their flight ability, were perceived as being capable of travelling freely across boundaries of various psychic and terrestrial landscapes. This helps explain why so many birds play major roles in Aboriginal 'Dreaming' stories. From the descriptions of the Adelaide landscapes contained in this paper, there appears to be at least two locations where an individual spirit resides after death, the sky world and the underworld.

In order to explain the apparent confusion over the destination of the dead person's spirit, we must investigate the Aboriginal conception of the spirit or soul. A comparison with beliefs from other parts of Australia indicates that Adelaide concepts of 'after life' were not unique and were, in fact, consistent with that of most other Aboriginal groups. On this matter, Berndt and Berndt state:

In ordinary life a man plays many roles, and in this respect the new situation [death] is not altogether dissimilar. One part of him in spirit form may be a trickster, another may go on to the Land of the Dead, or return to a nucleus of

60 Letter by Wyatt to the Colonial Secretary, 1 April 1838, 69/1838, Public Records Office, Adelaide.

61 Wyatt 1879:164,177,181.

62 Wilhelmi 1860 . This bird is possibly a species of tern.

63 Teichelmann and Schürmann 1840:2:9; Schürmann, Personal diaries, 23 January 1840; Gell 1988. A variation in the recording of karkanya is narkanya. 
spirit children awaiting rebirth, merge with the great ancestral and creative beings and so on. 64

We must therefore include such psychic landscapes in the study of Aboriginal views of their total landscape.

\section{Adelaide as a Lower Murray landscape}

I will now draw attention to problems that have arisen with the process of defining particular cultural traits as being 'Adelaide'. As will be shown in the following discussion, there has been a general failure by 20 th century scholars to acknowledge and account for Aboriginal reactions to the colonial situation in their ethnographic reconstructive work for southem South Australia. From the very beginning of European settlement, Aboriginal people were attracted by the availability of a new technology from European settlements. The very existence of the colonisers, initially explained within Aboriginal cosmology, aroused curiosity amongst Aboriginal people from far beyond the frontier. The gravitational effect of the city on Aboriginal demography is well illustrated by Cawthorne who says that by 1843 nearly all of the Mount Barker people, previously situated to the east about 35 kilometres away, were camped in Adelaide. He says:

if you ask them 'You Mount Barker [man]', 'No' they say and then again 'No' and explain themselves thus - 'long time ago me Mount Barker Man, now me long time set down at Adelaide, me now Adelaide man. ${ }^{65}$

The intention of foreign Aboriginal groups to incorporate themselves into the Adelaide settlement does not appear to have been generally welcomed by the original Adelaide inhabitants. There are several accounts of conflict between Adelaide people and neighbouring groups suggesting this. For instance, in 1844, an Adelaide Aboriginal man, known to Europeans as King John, said:

Before white man come, Murray black fellow never come here. Now white man come, Murray black fellow come too. Encounter Bay and Adelaide black fellow no like him. Me want him to go away. Let them sit down at the Murray, not here. This is not his country. 66

It is likely that the Adelaide people considered that they had more rights, than did other Aboriginal groups, to the rations and other goods available in the city. ${ }^{67}$ The initial conflict and absorption of the Adelaide territory by other Aboriginal groups appears to have been in a pre-European fashion, reflected in a predominance of sorcery killings, ritualised fighting, and, as I will argue, the taking over of the landscape mythology. It is in relation to this last aspect, that I wish to discuss the Lower Murray influence on the recording of the 'Adelaide' Aboriginal ethnography.

The most detailed account available of a myth concerning the Adelaide landscape is of the Tjirbruke spirit who created such geographical features as freshwater springs and hills. 68

64 Berndt and Berndt 1981:476.

65 Cawthorne, Literarium diarium, 27 January 1843, CY reel 214, A103 items 1-8, frame no. 209.

66 The Adelaide Observer, 27 April 1844:5.

67 Foster 1989 provides a detailed account of the effects of South Australian ration depots on Aboriginal people.

68 Accounts of Tjirbruke are given by Tindale and Mountford 1936; Tindale 1987; Smith 1930:331-341; Harvey 1939; Berndt 1940b; Lucas 1989. Campbell 1985 questions whether Tjirbruke is an Adelaide myth. Variations in the recording of Tjirbruke include Chirr-bookie, Tjilbruke and Tjirbuke. 


\section{ADELAIDE AS AN ABORIGINAL LANDSCAPE}

Tjirbruke's mythological track runs along the Saint Vincent Gulf side of Fleurieu Peninsula from the vicinity of Adelaide, along the coast to Cape Jervis, and inland to Brukunga near Mount Barker. Tjirbruke finally turned into a bird, some versions say a blue crane (Ardea pacifica), others state a glossy ibis (Plegadis falcinellus). One problem this myth presents is that all recorded versions of it date from early 20th century, with no hint of it from the Teichelmann and Schürmann $1830-40$ period. Tindale, who provides the most detailed account, presents another problem as the bulk of his informants were not Adelaide descendants, but people from Encounter Bay, Lower Murray and the Coorong. Many of the verses Tindale recorded were in the Ramindjeri language of Encounter Bay, the Yaralde of the Lower Lakes, and the Tangane of the Coorong. Even the name of Tijirbruke appears linguistically to be a Lower Murray word, rather than a term from the recorded Adelaide language. Also in Tindale's version, the importance of the ngaitji, a Lower Murray term for a spirit familiar, is emphasised. ${ }^{69}$ Although there must have been considerable variation among versions Tindale heard, as shown by the shorter accounts of Tjirbruke from his contemporaries, Tindale failed to account for these inconsistencies. He simply selected what he considered to be a 'correct' version. Undoubtedly, Tindale's rigid notion of 'tribe' was a strong influence in his treatment of cultural information, such as myth, as existing in a more homogeneous way than should have been. Tindale standardised geographical knowledge in the Tjirbruke myth to such a degree that his final version could not have represented the views of the Kaurna, as he defines them.

Whether there would have been such detailed knowledge of this myth outside the broad Adelaide cultural region in pre-European times is difficult to determine. One explanation is that this mythology was imported by the Lower Murray/Encounter Bay groups after colonisation, when they extended their range along the lower Fleurieu Peninsula coast to fill a vacuum probably left by the previous Aboriginal population moving north into settled areas around Adelaide. By 1860 , Lower Murray Aboriginal people living on the Point McLeay Mission reportedly considered all the original Adelaide Aboriginal people to be dead. ${ }^{70}$ At this time, Lower Murray people were already seasonally camping at various spots along the coast between Encounter Bay and Adelaide. ${ }^{71}$ In 1899, there were groups of Point McLeay people living in the Adelaide district, such as on the banks of the Patawalonga at Glenelg. ${ }^{72}$ Once in place, the Tjirbruke mythology would have provided Aboriginal travellers with a valuable record of suitable camping spots and places to find freshwater springs. The taking over of an unoccupied region, or at least a sparsely inhabited landscape, would have amounted to a pre-European type response to a post-European situation. This level of integration of historical changes into mythology is similar to the 'Dreaming' track modifications recorded in the 1970s from displaced Pintupi people in the Western Desert. ${ }^{73}$ However, in spite of the absence of Tjirbruke accounts from the early ethnographies, it is possible that this mythology existed in some form amongst Adelaide

69 In the Encounter Bay language, ngaitye was listed as 'friend, countryman, protector' (Meyer 1843:86). Taplin 1979:1 records this term in the Ngarrindjeri language to mean a 'tutelary genius or tribal symbol'.

70 Taplin, Journals, 31 January 1860.

71 The Taplin Journals 1859-1879 have many references to Point McLeay people travelling to Adelaide. Ross 1984:21 and Hemming 1985, 1987 record camping spots along the southern Fleurieu Peninsula coast that were used by Lower Murray people.

72 The Adelaide Observer, 11 November 1871:7. Also The Adelaide Observer, 2 September 1899:51.

73 Myers 1986:53-54 
people, and perhaps the neighbouring Encounter Bay people, in the pre-European period. Nevertheless, even if this myth was simply taken over later by foreign Aboriginal groups, such as the Lower Murray Lakes, Murray River and Coorong people, the newcomers nevertheless imparted their own cultural views into it, essentially reinventing a tradition.

Some recorded versions of myth bear more obvious innovations. One such modification involves the Ngurunderi myth epic of the Lower Murray people. A version, recorded in 1936, involves a very wide range of localities, from Mount Gambier in the Lower South East to the Adelaide district, a distance of over 360 kilometres. In this example, one of Ngurunderi's sons travelled from the Lower Murray to Mount Gambier, and was chased by a 'big devil' named Mirka, who emerged from the Blue Lake. ${ }^{74}$ Ngurunderi's son fled up the Coorong, across the Mount Lofty Ranges to Willunga which is 40 kilometres south of Adelaide. Ngurunderi, saw them approach, attacked and wounded Mirka at Red Ochre Cove. The congealing blood of the 'devil' formed a rich red ochre deposit at this place, now part of an Adelaide outer suburb. Mirka fled back to the Mount Gambier district, his dripping blood creating other ochre outcrops on the way. This particular version of the Ngurunderi myth is unique among the recorded mythologies of southern South Australia for its extremely broad geographic coverage. The mythical sites of other known versions of Ngurunderi are contained within the South East cultural bloc. The existence of the broader account is probably best explained in terms of post-colonial Aboriginal people gaining extensive geographical knowledge through participation in early statewide agricultural activities, such as shearing and harvesting. The importance of Red Ochre Cove, in the post-contact situation, is indicated by the record of Lower Murray people from Point McLeay Mission, travelling to Noarlunga to obtain initiation ochre in 1860.75 The construction of mythology would not have been restricted to a time long before European invasion, but has been a continuing process.

Another Adelaide landscape myth, showing a Lower Murray influence, is the legend of Pootpobberrie, which explains the formation of Waterfall Gully. ${ }^{76}$ A number of Aboriginal words have been recorded in association with it, some of which are linked to Adelaide

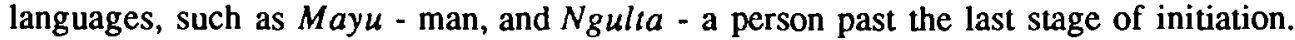
However, other words are obviously derived from non-Adelaide Aboriginal languages. For example, Miminnie - woman, and Muldarbie - sorcerer/spirit, are words that have only been recorded from Lower Murray languages. ${ }^{77}$ The term, Wirwirri-maldie for a sorcerer, is probably derived from the Encounter Bay word, wiwiri-malde - 'doctor, one who cures or charms away sickness'. ${ }^{78}$ This recorded version of the myth has clearly received a significant influence from the Lower Murray region.

It is my argument that the researcher acquiring ethnographic accounts of a culture, must always consider both the post-colonial history of the group concerned, and the varied cultural affinities of primary informants. The cultural influences operating must be identified, whenever possible. Unfortunately, in recent times, myths such as Tjirbruke and Pootpobberrie, have been too readily absorbed by some as part of the growing body of literature concerning the 'Kaurna' people of Adelaide, without recognition of possible

74

75

Tindale in The Advertiser, 16 May 1936.
Taplin, Journals, 12 September 1860.

7he Public Service Review, Adelaide, February 1913. (Reprinted in Journal of the Anthropological Society of South Australia 21(2), 1983:4).

77

78

Meyer 1843:107.

Meyer 1843:19,52,76. 
foreign Aboriginal influences. ${ }^{79}$ Accounts of mythology and other cultural expressions are not passed on to different cultural groups without some degree of interpretation, and therefore modification, having taken place.

\section{Discussion}

Aboriginal relationships to the land have, in the past literature, been treated as a somewhat uniform set of linkages, classified according to 'tribal' divisions. The data provided here suggest that Aboriginal views of the landscape are not easily grouped into such units. One of the results of using the outdated anthropological concept of the 'tribe', has been the incorrect treatment of pre-European Aboriginal culture as existing in more or less homogenous conditions. This has led to serious flaws in the reconstructive ethnographic work of various authors. For instance, many ethnographers have tended to look for 'correct' versions of cultural expressions, such as myths, when many equally valid forms exist. Another flawed assumption has been that Aboriginal culture is primarily static, resistant to change in its pre-European state, with post-European cultures being over simplified by an imposition of a 'traditional'/non-traditional' dichotomy. From the brief historical reconstruction given in this paper, I have indicated several probable examples of the reinvention of tradition, not easily explained by 'detribalisation' and 'assimilation' concepts.

The influences affecting 'Adelaide' culture have been cross-cultural in several ways. Firstly, in the sense that foreign Aboriginal groups, such as those from the Lower Murray, have had a significant affect on the recording of 'Adelaide' Aboriginal culture, particularly after the Teichelmann and Schürmann period. Secondly, that Europeans have been a major influence on the construction of beliefs concerning supposedly pre-European Aboriginal culture. This effect was not simply confined to the missionary period, but has been particularly strong during and since the reconstructive work by Tindale. Both sets of influence have combined to shape modern concepts of pre-European Adelaide Aboriginal culture, typified by the use of 'Kaurna' for the name of this group. The continuing widespread institutionalisation of the concept of 'Kaurna' has meant that this term will continue to be used in the future. The making of tradition is therefore a process that is still strong today, involving people from a variety of cultural backgrounds.

\section{Acknowledgments}

This paper was read out at a seminar held in the Geography Department of the University of Adelaide on the 29 October 1990. Comments on drafts of this paper were received from Chris Anderson, Peter Smailes, Kingsley Garbett, Robert Foster, Suzi Hutchings and Steve Hemming.

\section{BIBLIOGRAPHY}

Angas, G.F. Original sketches for South Australia Illustrated, 1847. Anthropology Archives, South Australian Museum.

Berndt, R.M. 'A curlew and owl legend from the Narunga tribe, South Australia', Oceania $10(4), 1940 \mathrm{a}: 456-462$.

'Some aspects of Jaraldi culture, South Australia', Oceania 11(2), 1940b:164-185.

Berndt, R.M and C.H.Berndt. The world of the first Australians. Sydney, 1981.

Groome 1983:3. 


\section{ABORIGINAL HISTORY $1991 \quad 15: 1$}

Black, J.M. 'Vocabularies of four South Australian languages: Adelaide, Narrunga, Kukata, and Narrinyeri - with special reference to their speech sounds', Transactions of the Royal Society of South Australia 44, 1920:76-93.

Brock, P. and D.Kartinyeri. Poonindie. The rise and destruction of an Aboriginal agricultural community. Adelaide, 1989.

Campbell, V.M. 'Is the legend of Tjilbruke a Kaurna legend?', Journal of the Anthropological Society of South Australia 23(7), 1985:3-8.

Cawthome, W.A. Literarium diarium, 1842-1843. Microfilm copy held at the Mortlock Library, Adelaide.

.'Rough notes on the manners and customs of the natives', Proceedings of the Royal Geographical Society of Australasia, South Australian Branch 27, 1926:44-77 (MS 1844 held in the Public Library of South Australia, Adelaide).

Clarke, P.A. 'Fruits and seeds as food for southern South Australian Aborigines', Journal of the Anthropological Society of South Australia 23(9), 1985:9-22.

'Aboriginal use of plant exudates, foliage and fungi as food and water sources in southern South Australia', Journal of the Anthropological Society of South Australia 24(3), 1986a:3-18.

'The study of ethnobotany in southern South Australia', Australian Aboriginal Studies

2, 1986b:40-47.

- 'Aboriginal uses of plants as medicines, narcotics and poisons in southern South

Australia', Journal of the Anthropological Society of South Australia 25(5), 1987:3-23.

'Aboriginal use of subterranean plant parts in southern South Australia', Records of

the South Australian Museum 22(1), 1988:63-76.

'Aboriginal non-plant medicines in southern South Australia and western Victoria', Journal of the Anthropological Society of South Australia 27(5), 1989:1-10.

'Adelaide Aboriginal cosmology', Journal of the Anthropological Society of South Australia 28(1), 1990:1-10.

. Post 1800 Aboriginal populations living on Kangaroo Island. Unpublished MS, 1990.

The mythical landscapes of the Lower Murray. Unpublished MS, 1991.

Crawford, I.M. Traditional Aboriginal plant resources in the Kalumburu area: aspects in ethno-economics', Records of the Western Australian Museum, supplement no.15, 1982.

Cumpston, J.S. Kangaroo Island 1800 - 1836. Canberra, 1970.

Davis, S. Man of all seasons: an Aboriginal perspective of the natural environment. Sydney, 1989.

Elkin, A.P. The Australian Aborigines: how to understand them. Sydney, 1964. . Aboriginal men of high degree. St Lucia, 1977.

Ellis, R.W. An historical geography of the pre-European inhabitants of the Adelaide Plains. Thesis, Geography Department, University of Adelaide, 1968.

. 'The Aboriginal inhabitants and their environment', in C.R.Twidale et al eds., Natural History of the Adelaide region. Adelaide, 1976.

Finlayson, W. 'Reminiscences by Pastor Finlayson', Proceedings of the Royal Geographical Society of South Australia 6, 1903:39-55.

Finnis, H.J. Early settlers on islands in Bass Straits. Adelaide, n.d.

Flinders, M. Voyage to Terra Australis, 2 vols. London, 1814. (Facsimile edition in the State Library of South Australia, Adelaide.)

Foster, R. The Bunganditj: European invasion and the economic basis of social collapse. Thesis, History Department, University of Adelaide, 1983.

'Feasts of the full-moon: the distribution of rations to Aborigines in South Australia: 1836-1861', Aboriginal History 13(1), 1989:63-78.

Gara, T. The life of Ivaritji ('Princess Amelia') of the Adelaide tribe', Journal of the Anthropological Society of South Australia 28(1), 1990:64-104. 


\section{ADELAIDE AS AN ABORIGINAL LANDSCAPE}

Gell, J.P. The vocabulary of the Adelaide tribe', Journal of the Anthropological Society of South Australia 25(5), 1988:3-15. (Originally published in Tasmanian Journal of Natural Science 1(2), 1842:109-124.)

Gott. B. 'Ecology of root use by the Aborigines of southern Australia', Archeology in Oceania 17, 1982:59-67.

. 'Murnong - Microseris scapigera. A study of a staple food of Victorian Aborigines', Australian Aboriginal Studies 2, 1983:2-17.

The uses of ethnohistory and ecology', Tempus 1, 1989:197-213.

Groome, H. The Kaurna, first people in Adelaide. Adelaide, 1981.

. 'A Kauma legend', Journal of the Anthropological Society of South Australia 21(2), 1983:3.

'Kauma occupation of the Adelaide Plains 1836', in T.Griffin and M.McGaskill, eds., Atlas of South Australia. Adelaide, 1986.

Hallam, S.J. Fire and hearth: a study of Aboriginal usage and European usurpation in southwestern Australia. Canberra, 1975.

Harvey, A. Field Notebook. Fry Collection, South Australian Museum, Anthropology Archives, Adelaide, 1939.

Hemming, S.J. 'Aborigines at Port Willunga: reminiscences of Thomas Martin', Journal of the Anthropological Society of South Australia 23(9), 1985:24-28.

. 'Reminiscences of Aborigines in the Adelaide Hills', Journal of the Anthropological Society of South Australia 25(4), 1987:3-8.

Hemming, S.J. and P.A. Clarke. Aboriginal people of South Australia. Canberra, 1989.

Howitt, A.W. Native tribes of south-east Australia. London, 1904.

Jacobs, J.M. 'Women talking up big: Aboriginal women as cultural custodians, a South Australian example', in P.Brock, ed., Women rites and sites. Sydney, 1989.

Jones, R. 'Fire-stick farming', Australian Natural History 16, 1969:224-228.

Kartinyeri, D. The Rigney family genealogy. Adelaide, 1983. The Wanganeen family genealogy, Adelaide, 1985.

'Pema Adjunda Rudkee ('King James Rodney')', in Tandanya Opening Day Souvenir Program, 1 October 1989. Adelaide, 1989a.

. 'Introduction', in Tandanya Opening Day Souvenir Program, 1 October 1989. Adelaide, $1989 \mathrm{~b}$.

The Wilson family genealogies, 2 vols. Adelaide, 1990.

Lucas, R. The anthropological significance of Aboriginal sites at Sellicks beach. A report to the Aboriginal Heritage Branch, South Australian Department of Environment and Planning, Adelaide, 1989.

Mattingley, C. and K. Hampton, eds. Survival in our own land. Adelaide, 1988.

Meyer, H.A.E. Vocabulary of the language spoken by the Aborigines of... South Australia...preceded by a grammar... Adelaide, 1843.

Myers, F.R. Pintupi country, Pintupi self: sentiment, place, and politics among Western Desert Aborigines. Canberra, 1986.

Moorhouse, M. 'A vocabulary ... of the Murray River language...', in T. Parkhouse, ed., The Autochthones of Australia. Adelaide, 1935.

Oates, W.J. and L.F.Oates. A revised linguistic survey of Australia. Canberra, 1970.

Peterson, N. ed. Tribes and boundaries in Australia. Canberra, 1976.

Reynolds, H. With the white people. Melbourne, 1990.

Ross, B. ed. Aboriginal and historic places around metropolitan Adelaide and the south coast. Adelaide, 1984.

Schürmann, C.W. Personal diaries, 1839-40. Typescript edited by E.A. Schürmann. Copy held in the Aboriginal Heritage Branch of the Department of Environment and Planning, Adelaide. . A vocabulary of the Parnkalla language ... Adelaide, 1844. 


\section{ABORIGINAL HISTORY $1991 \quad 15: 1$}

- The Aboriginal tribes of Port Lincoln in South Australia, their mode of life, manners, customs, etc.' in J.D. Woods ed., The native tribes of South Australia, pp.207-251. Adelaide, 1879.

Smith, W. R. Myths and legends of the Australian Aboriginals. London, 1930.

Stephens, E. The Aborigines of Australia', Royal Society of New South Wales 23, 1889:476503.

Sweetman, R.T. 'Aborigines of the Encounter Bay area: reminiscences of R.T. Sweetman', The Register, March 1928. (Extracts have been published in Journal of the Anthropological Society of South Australia 26(7), 1988:3-5.)

Taplin, G. Journals, 1859-79. South Australian Archives.

. 'The Narrinyeri', [1874], in J.D. Woods ed., The native tribes of South Australia. Adelaide, 1979.

. Folklore, manners, customs and languages of the South Australian Aborigines. Adelaide, 1879.

Teichelmann, C.G. Aborigines of South Australia ... Adelaide, 1841. . Dictionary of the Adelaide dialect. MS, 1875, South African Public Library.

Teichelmann, C.G. and C.W.Schurmann. Outlines of a grammar, vocabulary and phraseology of the Aboriginal language of South Australia ... Adelaide, 1840.

Tindale, N.B. 'Notes on the natives of the southern portion of Yorke Peninsula, South Australia', Transactions of the Royal Society of South Australia 60, 1936:55-70.

'Distribution of Australian tribes: a field survey', Transactions of the Royal Society of South Australia 64(1), 1940:140-231.

Aboriginal tribes of Australia: their terrain, environmental controls, distribution, limits, and proper names. Canberra, 1974.

The wanderings of Tjirbruki: a tale of the Kauma people of Adelaide', Records of the South Australian Museum 20, 1987:5-13.

Tindale, N.B. and C.P.Mountford. 'Results of the excavation of Kongarati Cave near Second Valley, South Australia', Records of the South Australian Museum 5(4), 1936:487-502.

Twidale, C.R., M.J.Tyler and B.P.Webb. The natural history of the Adelaide region. Adelaide, 1976.

Warner, W.L. A black civilization.: a social study of an Australian tribe. New York, 1964.

Webb, N.A. 'The place names of the Adelaide tribe', in Municipal Year Book 1936-7, City of Adelaide. Adelaide, 1937.

Wilhelmi, C. 'Manners and customs of the Australian natives, in particular of the Port Lincoln district', Transactions of the Royal Society of Victoria 5, 1860:164-203 (Typescript of paper is held in the South Australian Museum).

Williams, W. The making of the South Australian landscape: a study in the historical geography of Australia. London, 1974.

. A vocabulary of the language of the Aborigines of the Adelaide district... Adelaide, 1839. (Reprinted in the South Australian Colonist, 7 July 1840:295-296. Also reprinted in T.A. Parkhouse ed., Reprints and papers relating to the autochthones of Australia, pp.57-70. Woodville, 1926.)

Wyatt, W. 'Some account of the manners and superstitions of the Adelaide and Encounter Bay tribes: with a vocabulary of their language, names of persons and places etc.', in J.D. Wood ed., Native tribes of South Australia, pp.157-181. Adelaide, 1879. 